Ilmu Pertanian (Agricultural Science)

Vol. 1 No. 3 December, 2016 : 130-136

Available online at http://journal.ugm.ac.id/jip

DOI: doi.org/10.22146/ipas.11227

\title{
Consumer Willingness to Pay of Organic Rice and The Factors which Affected in Pontianak
}

\author{
Heru Setiyadi*, Slamet Hartono, Dwidjono Hadi Darwanto \\ Department of Agricultural Socio Economics, Faculty of Agriculture, Universitas Gadjah Mada \\ Jln. Flora no. 1, Bulaksumur, Sleman, Yogyakarta 5528, Indonesia \\ *Corresponding email: heru.setiyadi@mail.ugm.ac.id
}

Received: $17^{\text {th }}$ May 2016 ; Revised: 27th June 2016 ; Accepted: $21^{\text {st }}$ August 2017

\begin{abstract}
Organic rice is claimed as one of staples food alternative choice. Consuming organic rice is not only about fulfilling the quality needs but also a part of life style. Organic rice is also available in many modern retails in Pontianak so that it is affordable enough to be consumed by Pontianak's residents. The aims of study were to analyze Willingness To Pay (WTP) of consumers with Contingent Valuation Method (CVM) and find factors affected consumers WTP value of organic rice . Primary data were collected during March to April 2016 and analyzed by multiple regression. The samples of Pontianak's residents were used as respondents. The result showed that willingness to pay rate of organic rice in Pontianak was low. The age, price of organic rice, ergonomic packaging, respondent expenditure in month, and non-organic rice price affected WTP with marked positive, while marital status factor had negative marked.
\end{abstract}

Keywords: Consumers, Contingent Valuation Method, Organic Rice, Willingness To Pay

\section{INTRODUCTION}

With population growth, agriculture will need to produce enough supply of food to feed an expected more than eight milliard people by 2030 (Pouratashi, 2012). When population and prosperity of society increased, need of the types and quality of food products, especially rice, has to increased and diversified (Kementerian Pertanian RI, 2014). The market growth of organic food products in Indonesia grew rapidly and was characterized by an increasing number of farmers who manages organic agriculture from year to year, increasing organic outlets in supermarkets and restaurants, increasing organic lovers organizations, NGOs and the Institute of Organic Certification (Anonymous, 2015).

One of organic food products with positive trend was the willingness to buy organic rice. It can be seen on the demand and consumption of organic rice as well as the beginning of their development of modern retail in providing organic rice. Ibitoye et al. (2014) stated that knowledge towards organic rice among consumers is fundamental to induce demand and market for organic rice. Hanis et al. (2012) said that the most important attribute for rice was food safety, followed by taste and size of grain and consumers were also willing to pay premium prices for the demanded attributes. These organic rice was traded and recognized its presence in Pontianak.

Since the organic rice had beneficial for healthy, it became potential to be a new trend. Marketing of organic rice in Indonesia particularly in Pontianak constrained by perception of price which considered expensive. Producers should think how to set the selling price of organic rice precisely to generate consumers interest. So it can lead to the willingness to pay for the product. The perpetrators, instigators, and marketer of organic rice in Pontianak who want to determine the selling price should conduct the selling market strategies and know the willingness to pay and factors that influence it.

Suwanda (2012) conducted a study on WTP rice analog in the Serambi Botani, Botany Square, Bogor using Contingent Valuation Method (CVM) with the results of the average WTP was higher than the price offered Serambi Botani and the factors that influence it, namely the level of education, employment, income, level of concern for food diversification, and knowledge of analog rice. Husodo and Bharoto (2009) examined the WTP consumers towards organic agricultural 
products in the municipality of Yogyakarta using CVM. The result indicated the majority of respondents $(60 \%)$ are not willing to pay the allegedly due to lack of awareness of the benefits of organic products, organic product quality assurance doubt. Variables that affected significantly positive were product safety, environmental benefits, the difference with non-organic products, pesticide used, price, taste, labeling, age, gender, education level, and income level. While the variable marital status showed a negative influence.

Cerda et al. (2012) applied the contingent valuation method using a logistic probability function and a single-bound dichotomous choice format. This study also estimated the marginal willingness to pay (WTP) of consumers for organic apples by using conjoint analysis with ranking procedures. The results showed that the estimation of part-worth utilities of each attribute confirmed the Fuji variety, organic method of production, sweet apples and lowest price were the most preferred levels of each attribute.

Iwamoto (2012) used CVM analysis method and showed the willingness of consumers to pay to the low calorie content variable with a range of 800-900 yen $/ 5 \mathrm{~kg}$. The price variable was significant at the 1 percent level and have a negative correlation. Low-calorie variable was significant at the 10 percent level and had a negative correlation. Hidayati (2013) stated that marital status affected WTP organic vegetables. Meanwhile, Celona (2015) said that the willingness to pay for organic vegetables was not only influenced by the status of marriage, but also by age and gender. Sari and Setiartiti (2015) concluded that factors influence the amount of willingness to pay was age (positive influence and significant towards willingness to pay), education period, income, children bearing and the means.

There are no infomation about the average value of willingness to pay consumers toward organic rice and non organic rice and the factors that affect the value of willingness to pay consumers of organic rice in Pontianak. The study aimed to 1) determine the average value of willingness to pay consumers toward organic rice and non organic rice; 2) determine the factors that affect the value of williness to pay consumers of organic rice.

\section{MATERIALS AND METHODS}

This research was carried out in Pontianak, West Kalimantan Province because it was one area of marketing of organic rice and the region with the most modern retail that sold organic rice in West Kalimantan. This research had been held March-April 2016. The population in this research was the entire population of the Pontianak, whose territory has modern retail. The sample was determined by non-probability sampling methods or non random sampling (Soewadji, 2012). Determination of samples were selected using the method of accidental sampling or convenience sampling of 100 respondents as discribed by Prasetyo (2008). The variables in this research were the factors that affected WTP organic rice in Pontianak as the dependent variable. The independent variables include age, level of education, total spending per capita, price of non-organic rice, dummy gender, employment or unemployment status as a dummy, dummy marital status, dummy organic rice price levels, dummy health levels, and dummy ergonomic packaging. Data were collected using questionnaire.

To determine the value of WTP organic rice consumer, researcher used the Contingent Valuation Method approach, namely direct approach to survey asking about the value of willingness to pay for organic rice to the respondent (Fauzi, 2006). The steps as followed:

\section{Market hypothetic}

Market was hypothetically contained definition of organic rice, type of organic rice with the criteria, and modern retailers in Pontianak. Hypothetical market aims to make the perception of respodents and make it easy to understand describtion, type, merk, and size of organic rice.

The hypothetical market were: Organic rice is rice with the label "Organic" on the packaging that is free from chemical fertilizers, non preservatives, non bleach, contain natural fibers as well as the use of certified standardized institutions. Organic rice distributed in modern retail (Super Market, Hypermarket, Minimarket) in Pontianak generally was organic rice red, white, black, and brown with a variety of brands such as Pandan Green, Tropicana Slim, Holistic Bio Organic, Cap 88, RI 1, and others who have packaging sizes $1 \mathrm{~kg}, 2 \mathrm{~kg}, 3 \mathrm{~kg}, 4 \mathrm{~kg}$, and $5 \mathrm{~kg}$.

\section{Finding WTP value}

This phase was conducted through a survey used a questionnaire to obtain WTP value (price) of respondents willing to pay a maximum of organic rice. The initial value (starting point) taken was the maximum price of organic rice applicable in Pontianak Rp 37,000/kilogram. If respondents were not willing to pay that price, then the value written down to the lowest value of $\operatorname{Rp} 20,000$ or agreed upon a certain value, and vice versa.

Calculate an estimate of the average value of WTP

This value is calculated based on the value obtained 
in the previous stage. Estimation the average WTP could be calculated by the formula:

$\mathrm{EWTP}=\sum_{i=0}^{n} W_{i} P f_{i}$

Information: EWTP = Estimation the average WTP respondent of organic rice (Rupiah); Wi $=$ The $\mathrm{i}-$ Value of WTP (Rupiah); $\mathrm{Pf}_{\mathrm{i}}=$ The i-relative frequency of class WTP to $-\mathrm{i} ; \mathrm{n}=$ Class number of WTP, $\mathrm{i}=$ The i-respondent $(i=1,2, \ldots, n)$.

\section{Estimating the value curve of WTP}

The value curve obtained by regression to the WTP value as dependent variable with several independent variables. In this research, nominal value curve of WTP organic rice obtained by the equation:

$\mathrm{WTP}=\mathrm{f}$ (Usia, LmPend, JmlPeng, Hbno, D1JenKel, D2StaPek, D3StaPer, D4Thbo, D5TkKes, D6 KemErgo)....(2) Information: WTP $=$ Value of WTP respondent of organic rice per kilogram (Rupiah); Usia = Level of age (years); LmPend = Level of education (years); JmlPeng = Total spending per capita (Rupiah/ Month); Hbno = Non-organic rice price (Rupiah/Kilogram); D1JenKel = Dummy gender $($ Female $=1$ and male $=0) ;$ D2StaPek $=$ Employment or unemployment status as a dummy (Employment $=1$ and unemployment $=0$ ); D3StaPer $=$ Dummy marital status (married $=1$ and unmarried $=0$ ); D4Thbo = Dummy level of organic rice price (expensive $=1$ and cheap $=0$ ); D5TkKes = Dummy level of healthy (healthy rice $=1$ and unhealthy rice $=0$ ); D6KemErgo = Dummy level of ergonomic packaging $($ ergonomic $=1$ and non-ergonomic $=0)$

\section{Aggregating data of WTP mean}

Total value WTP of respondents were calculated based on data from respondents WTP value distribution. WTP average value that had been obtained then been multiplied by the number of respondents. The equation of the total value WTP organic rice respondents were:

TWTP $=$ EWTP.Ni.

Information: TWTP $=$ Total value WTP of organic rice respondent (Rupiah); EWTP $=$ Estimated of the average value WTP of the organic rice respondent (Rupiah); $\mathrm{Ni}=$ population number of organic rice respondent (person).

Factors that influence the consumer WTP organic rice in Pontianak using multiple linear regression, and regression of dummy variables. The models alleged multiple linear regression analysis used in this research, followed by:

$$
\mathrm{Y}=\mathrm{a}+\mathrm{b} 1 \mathrm{Usia}+\mathrm{b} 2 \mathrm{LmPend}+\mathrm{b} 3 \mathrm{Jm} 1 \text { Peng }+
$$

b4Hbno + b5D1JenKel+ b6D2StaPek + b7D3StaPer+ b8D4Thbo + b9D5TkKes + b10D6KemErgo + e.

The above equation model created an advanced equation in the form of multiple linear way of doing logarithms of the equation was to facilitate prediction (Gujarati, 2006). So from an advanced form multiple linear equations can be analyzed using the OLS method to obtain parameter or regression coefficient. The form of the equation was:

Ln $\mathrm{Y}=\mathrm{a}+\mathrm{b} 1$ LnUsia + b2LnLmPend + b3LnJmlPeng + b4LnHbno + b5D1JenKel + b6D2StaPek + b7D3StaPer + b8D4Thbo + b9D5TkKes + b10D6KemErgo + e

Information: $\mathrm{Y}=$ Value of WTP respondent of organic rice per kilogram (Rupiah); $a=$ Constanta; $b 1-b 10$ $=$ Coefficient of model; Usia $=$ Level of age (years); LmPend $=$ Level of education (years); JmlPeng = Total spending per capita (Rupiah/ Month); Hbno = Non-organic rice price (Rupiah/Kilogram); D1 JenKel $=$ Dummy gender $($ Female $=1$ and male $=$ 0 ); D2StaPek = Employment or unemployment status as a dummy (Employment $=1$ and unemployment $=$ 0 ); D3StaPer $=$ Dummy marital status (married $=1$ and unmarried $=0)$; D4Thbo $=$ Dummy level of organic rice price $($ expensive $=1$ and cheap $=0)$; D5TkKes $=$ Dummy level of healthy (healthy rice $=1$ and unhealthy rice $=0$ ); D6KemErgo = Dummy level of ergonomic packaging (ergonomic $=1$ and non-ergonomic $=0$ ); $\mathrm{e}=$ Error.

\section{RESULT AND DISCUSSION}

\section{Research Area Describtion}

Pontianak is located near ASEAN developed countries such as Malaysia, Brunei Darussalam, and Singapore. Besides that, Serawak Malaysia is the nearest one so Pontianak has a great and possible access related to bilateral connection between Indonesia and Malaysia. Pontianak is the capital city of West Kalimantan and consists of 6 sub districts with 29 villages. It also has 534 rukunwarga and 2,372 rukunwarga as one of social organization. It also has $107.82 \mathrm{~km}^{2}$ in width. The population rose significantly year by year. In 1990, the population was 431,328 and in 2000 rose up to 464,534 . The rate of population growth was $7.7 \%$ during the year. In the next decade, the population growth was about $19.42 \%$ so total population in 2010 was 554,764 (BAPPEDA Kota Pontianak, 2015).

The $32.42 \%$ of 10 -year-old-population finished their education in high school overwhelming senior high school and vocational high school. More than 


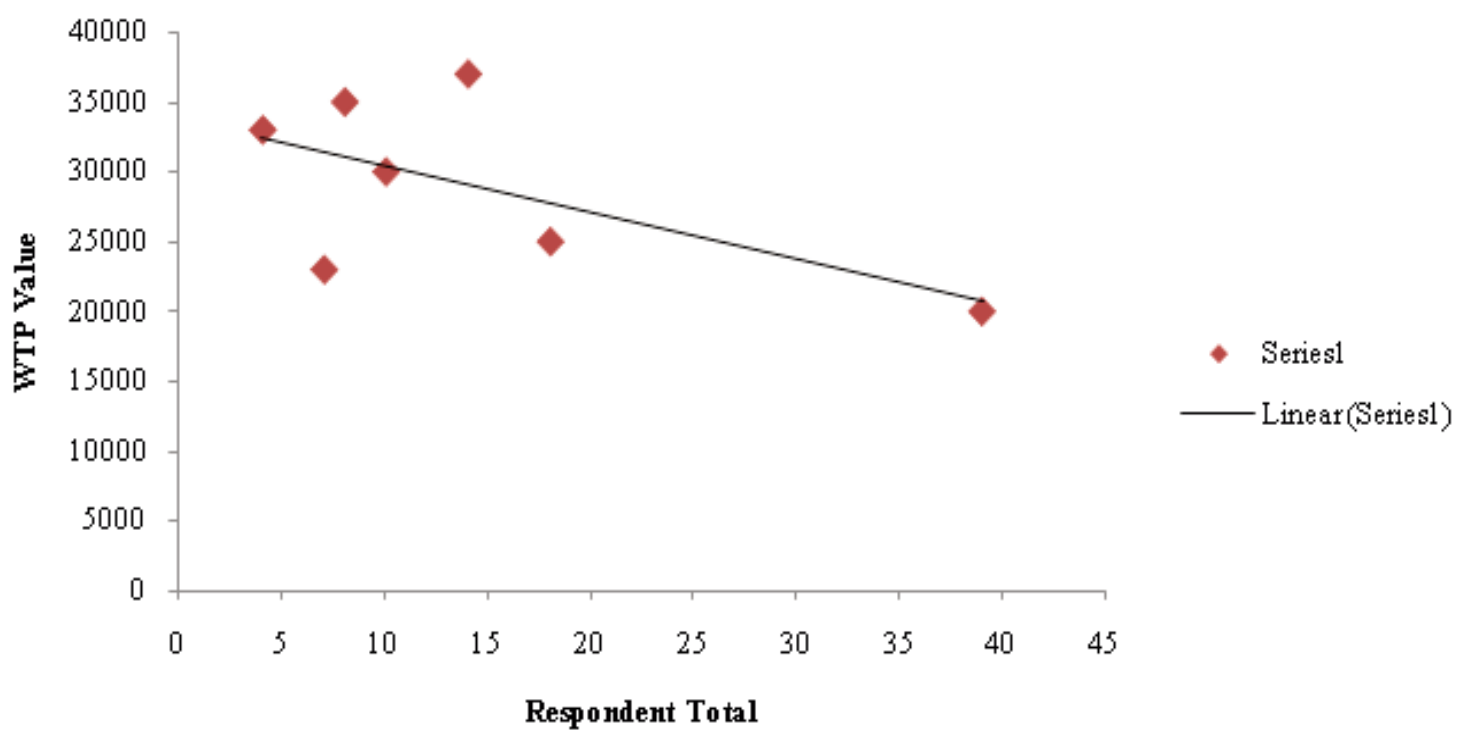

Figure 1. Respondents WTP organic rice curve in Pontianak

Table 1. Multiple Regression Analysis For Factors Consumer WTP Value of Organic Rice in Pontianak

\begin{tabular}{lccc}
\hline \multicolumn{1}{c}{ Variable } & Coefficient & t-statistic & Prob. \\
\hline C & 1.4882 & 0.9933 & 0.3232 \\
Ln Level of age & $0.4718^{* * *}$ & 4.8801 & 0.0000 \\
Dummy level of healthy & -0.0777 & -1.3772 & 0.1719 \\
Dummy level of organic rice price & $0.0784^{* *}$ & 2.3358 & 0.0217 \\
Dummy marital status & $-0.0879^{* *}$ & -2.2746 & 0.0253 \\
Employment or unemployment status as a dummy & -0.0243 & -0.6827 & 0.4966 \\
Dummy level of ergonomic packaging & $0.1001^{* *}$ & 2.4124 & 0.0179 \\
Ln Level of education & 0.0751 & 0.7979 & 0.4271 \\
Ln Total spending per capita & $0.1995^{* * *}$ & 4.8540 & 0.0000 \\
Dummy gender & -0.0128 & -0.3953 & 0.6936 \\
Ln Non-organic rice price & $0.4173^{* *}$ & 2.4419 & 0.0166 \\
\hline R- Square $=0.6334$ & Prob(F-statistic) & & \\
F-statistic $=15.3798$ & $=0.0000$ & & \\
\hline
\end{tabular}

Remarks: $* * *=$ significantin error $1 \% ; * *=$ significant in error $5 \% ; *=$ significant in error $10 \%$

Source: Primary data, 2016 (Calculated)

a half of population $(59.47 \%)$ was a part of workforce and $40.53 \%$ remained a part of non-workforce ( BAPPEDA Kota Pontianak, 2015). The Human Development Index (HDI) increased from 72.41 in 2009 into 74.64 in 2013. Economic condition which was composed by 8 economic sectors in 6 sub districts increased in 2014. All sectors had a significant growth. The highest sector in growth was transportation and communication sector and the most contributive sector in PDRB was trade and hotels, and construction sector.

\section{Respondents Characteristic}

Most of respondents sex of the research was female $(60 \%)$ because women had a higher willingness to pay than those men (Daulay, 2012). According to Abdillah (2014), at this age, they had the highest premium willingness to pay among others age. Working respondents were $68 \%$ and remained $32 \%$ were unworked respondents. Most of respondents were graduated from diploma. The higher education of the respondents they had, the more responsive they would be. They also had a higher awareness of the importance of healthy food. Education was also affected in their decision to choose some products and brands.

Most of respondents expenditure (32\%) was between $\mathrm{Rp} \mathrm{2,500,000.00-Rp} \mathrm{3,500,000.00} \mathrm{in} \mathrm{a}$ moth. Affordable price of organic rice which could be paid by respondents was Rp $12,000.00 / \mathrm{kg}$. It was $54 \%$ respondents who has been married. Respondents who raised children, used their income to fulfill households needs and more selective to choose their daily food because there was a responsibility to build a health family (Suwanda, 2012). Most of respondents $(67 \%)$ were also claimed that the price of organic rice was cheap enough. It was caused by their high income which affected their purchasing power. 
About $88 \%$ respondents claimed that organic rice was good for their healthy because it had no organic chemical input during its cultivation. There was $80 \%$ respondents who claimed that organic rice packaging was easy to open, flexible, and easy to bring (ergonomic).

\section{Value of WTP respondent of organic rice In Pontianak}

\section{Market hypothetic}

Market was hypothetically contained definition of organic rice, type of organic rice with the criteria, and modern ritailers in Pontianak. Hypothetical market aims to make the perception of respodents and make it easy to understand describtion, type, merk, and size of organic rice.

\section{Value of WTP}

Based on this research, 39 respondents of 100 respondents in Pontianak disposed to pay organic price in Rp 20,000.00 per kilogram as the cheapest price (the lowest WTP).

\section{Average value of WTP}

Based on the research, the WTP mean was about Rp 26,120.00 per kilogram. The WTP was higher than the retailed organic price $\mathrm{Rp} 20,000.00$ per kilogram. So it could be concluded that there was consumer surplus, Rp 6,210.00.

\section{Curve of WTP}

The curve showed total of respondent who chosen value of WTP (Figure 1). It was the curve of organic rice WTP in Pontianak.

\section{Agregat Data (Total WTP)}

Total respondents WTP was calculated by respondents distribution data. The mean of WTP was multiplied with sums of respondents. Based on the calculation, WTP of organic rice in Pontianak was Rp 2,621,000.00

\section{Factors Which Were Affected Consumer WTP Value Of Organic Rice In Pontianak}

There was the result of multiple regression analysis for factors which were affected in this research (Table 1).

Classical assumption for those results followed by:

\section{Normality}

The data had been normally distributed. It could be concluded from Jarque-bera test with 0.17 for probability and $17 \%$ was higher than its error level, $0.1(10 \%)$.

\section{Heteroscedasticity}

Based on that regression model, the probability of Obs*R-squared was 0.55 or $55 \%$. This value was higher than $10 \%$ as it error level. So, no heteroscedasticity was identified in these data.

\section{Multicollinearity}

In that regression model, correlation value among dependent variables was less than 0.8 so multicollinearity was not happened in these data.

Besides that, the variables were explained as follows:

\section{Level of age}

The variable had a positive regression coefficient that was 0.4718 . When the age of respondents were a increase $1 \%$, the WTP organic rice would increase $0.4718 \%$. It was caused by their needs of organic rice benefit so they disposed to pay in a higher price. Sumarwan (2011) stated that the older someone age they had, the higher they need the healthy food because they need to suffer and prevent from illness. Pramono (2012) stated that the older someone age they had, the more aware they would.

\section{Dummy Level of organic rice price}

Based on regression analysis, the price of organic price had a positive regression coefficient, 0.0784 . It could be concluded when organic rice had expensive price, WTP would increase for 0.0784 . Price was an important factor and so sensitive for consumers willingness to pay. High prices reflect the quality of product. According to research Utami (2011), organic rice with the good quality products caused consumers were willingness to pay although it has a high price. High education level of respondents who made a respondent responsive to the quality of organic rice

\section{Dummy Marital status}

The marital status had a negative regression coefficient, -0.0879 . It could be concluded that married respondents had decreasing willingness to pay. The result was supported by Hidayati (2013). She said that married respondents would minimize their willingness to pay organic vegetables.

\section{Dummy Level of ergonomic packaging}

From the regression analysis, the variable had a positif coefficient regression, 0.1001 . When organic rice had an ergonomic packaging, the willingness to pay would increase for 0.1001. Daulay (2012) stated that ergonomic packaging affected willingness to pay of vegetable-instant-noodles. Respondents claimed that ergonomic packaging had a good image so that they would to pay higher. 


\section{Total spending per capita per Month}

Based on regression analysis, the variable had a positif coefficient regression, that was 0.1995 . When each category of expenditures increased $1 \%$ the WTP increased $0.1995 \%$. Respondents whom had the high income could afford enough to buy organic rice (Suwanda, 2012). Pramono (2012) in Abdillah (2014) stated that the sum of expenditures in a month gave positif effect to consumer willingness to pay.

\section{Non-organic rice price}

Based on regression analysis, the variable had positif coefficient of regression, that was 0.4173 . When the price of organic rice increased $1 \%$ so WTP increased $0.4173 \%$. The higher price of non-organic rice caused the increasing of willingness to pay. Respondents assumed that price of organic rice was higher than non-organic one.

\section{CONCLUSION}

The result showed that willingness to pay rate of organic rice in Pontianak was low-categorized because the majority of the value of WTP obtained a minimum price (the lowest WTP). Factors which affected WTP were age, price of organic rice, ergonomic packaging, respondent expenditure in month, and non-organic rice price with marked positive but marital status factor with negative marked. In this research, policies was figured in organic producers policies to determine the price of organic rice in Pontianak.

\section{REFERENCES}

Abdillah, R. F. 2014. Analisis Kesediaan Membayar (Willingness To Pay) Produk Healthy Food Beras Merah Pulen di Serambi Botani, Botani Square, Bogor. Skripsi. Institut Pertanian Bogor.

Anonymous. 2015. Kementan: Pertanian Organik Berkembang Pesat. [online] Available at: http://industri.bisnis.com/read/20150130/99/3 97019/kementan-pertanian-organik berkembangpesat/ [Accessed 27 January 2016].

BAPPEDAKota Pontianak. 2015. Rencana Pembangunan Jangka Menengah Kota Pontianak 20152019. [online] Gambaran Umum Kota Pontianak. Available at: http:edoc.pontianakkota.go.id/ .../37-bab-ii-gambaran-umum/ [Accessed 28 March 2016].

Celona, N. 2015. Analisis Kesediaan Membayar Konsumen Beberapa Komoditi Sayuran Organik (Studi Kasus: Giant Hypermarket, Botani Square, Kota Bogor). Skripsi. Institut Pertanian Bogor.

Cerda, A. A., L. Y. Gracia, S. O. Farias, M. Alvaro, and Ubilla. 2012. Consumer Preferences and Willingness To Pay for Organic Apples. Ciencia e Investigación Agraria Agricultural Economics, 39(1): 47-59.

Daulay, M. D. 2012. Analisis Proses Keputusan Pembelian Konsumen Untuk Membayar (Willingness To Pay) Mie Instan Sayur di Serambi Botani, Botani Square, Bogor. Skripsi. Institut Pertanian Bogor.

Fauzi, A. 2006. Ekonomi Sumber Daya Alam dan Lingkungan Teori dan Aplikasi. Jakarta: Gramedia Pustaka Utama.

Gujarati, D. N. 2006. Dasar-Dasar Ekonometrika. Jakarta: Erlangga.

Hanis, A. I. A. H., S. Jinap, M. Nasir, R. Alias, and M. Shahrim. 2012. Consumers' Demand and Wllingness to Pay for Rice Attributes in Malaysia. International Food Research Journal, 19(1): 363-369.

Hidayati, N. 2013. Analisis Willingness To Pay untuk Sayuran Organik di Toko All Fresh Bogor. Skripsi. Institut Pertanian Bogor.

Husodo, S. and Bharoto. 2009. Willingness To Pay Konsumen Terhadap Produk Pertanian Organik (Studi Kasus di Kodya Yogyakarta). Jurnal Ilmu-Ilmu Pertanian Sekolah Tinggi Penyuluhan Pertanian Yogyakarta, 5(1): 31-37.

Ibitoye, O. O., N. M. Nawi, N. H. Kamarulzaman and N. Man. 2014. Consumer's Awareness towards Organic Rice in Malaysia. International Food Research Journal, 21(5): 1711-1718.

Iwamoto, H. 2012. Consumers' willingness-to-pay for low-calorie labeled Rice. Paper presented to the 56th Australian Agricultural and Resource Economics Society (AARES) annual conference, Freemantle, Australia, February 7-10.

Kementerian Pertanian RI. 2014. Buletin Konsumsi Pangan. Pusat Data dan Sistem Informasi Pertanian, 5(4): 1-65.

Pouratashi, M. 2012. Factors Influencing Consumers' Willingness To Pay for Agricultural Organic Products (AOP). International Conference on Applied Life Sciences (ICALS2012) ISALS: Conference Proceedings. Croatia: InTech, pp. 371-376.

Pramono, S.W. 2012. Analisis Willingness To Pay Konsumen terhadap Tahu Kita (Studi Kasus di Joyo Swalayan, Jakarta Selatan). Skripsi. Institut Pertanian Bogor.

Prasetyo, B,. dan L. M. Jannah. 2008. Metode Penelitian Kuantitatif: Teori dan Aplikasi. Jakarta: PT Raja Grafindo Persada.

Sari, H. P. dan L. Setiartiti. 2015. Willingness To Pay Perbaikan Kualitas Pelayanan Kereta Api. Jurnal Ekonomi dan Studi Pembangunan, 16 
(2): 200-209.

Soewadji, J. 2012. Pengantar Metodologi Penelitian. Jakarta: Mitra Wacana Media.

Sumarwan, U. 2011. Perilaku Konsumen Teori dan Penerapannya dalam Pemasaran. Bogor: PT Ghalia Indonesia.

Suwanda, A. D. 2012. Analisis Kesediaan Membayar
(Willingness To Pay) Beras Analog di Serambi Botani, Botani Square, Bogor. Skripsi. Institut Pertanian Bogor.

Utami, D. P. 2011. Analisis Pilihan Konsumen dalam Mengkonsumsi Beras Organik di Kabupaten Sragen. Mediagro, 7(1): 41-58. 